\section{Eosinophilic granulomatosis with polyangiitis can manifest lacrimal and salivary glands swelling by granulomatous inflammation: a potential mimicker of IgG4-related disease}

We read the paper by Vaglio et al in your journal with great interest. ${ }^{1}$ They reported that patients with eosinophilic granulomatosis with polyangiitis (EGPA), previously known as ChurgStrauss syndrome, showed high serum IgG4 levels, correlating with disease activity and the extent of organ involvement. ${ }^{1}$ Since then, the association between EGPA and IgG4-related disease has been discussed by researchers. ${ }^{2-4}$ EGPA is one of the systemic vasculitis and is typically preceded by bronchial asthma, allergic rhinitis and/or sinusitis and followed by peripheral blood eosinophilia and eosinophil infiltration into organs. IgG4-related disease is an emerging disease entity characterised by high serum IgG4 levels and marked IgG4-positive plasma cell infiltration at lesions. Mikulicz disease, a prototype of IgG4-related disease, presents with enlarged lacrimal and salivary glands and often has allergic features such as asthma and chronic sinusitis. Pathogenically, $\mathrm{T}$ helper type 2-related cytokines, which contributes to IgG4-class switching, is the common immunopathogenic pathway between EGPA and IgG4-related disease. ${ }^{5-7}$

Indeed, several cases of EGPA complicated with Mikulicz disease-like symptoms (lacrimal and salivary glands swelling) along with elevated serum IgG4 have been reported as shown in figure $1 \mathrm{~A} .{ }^{8-11}$ All of those cases showed elevated levels of serum $\mathrm{C}$ reactive protein, which are unusual in IgG4-related Mikulicz disease. ${ }^{12}$ Then, rheumatologists face with the following questions: 'Are the EGPAs concurrent with IgG4-related disease?' or
“Do the EGPAs just mimic IgG4-related disease?'. To address the issue, we reviewed literatures that reported cases with enlarged lacrimal and salivary glands who were diagnosed with EGPA histopathologically with biopsy samples (figure 1B). We regarded the presence of EGPA-specific histopathological findings as the key to answer the question and found that the enlarged lacrimal and salivary glands in patients with EGPA demonstrated eosinophilic granulomas, which is suggestive for EGPA and not consistent with IgG4-related disease (figure 1B). ${ }^{13-15}$ Thus, the inflammation of the enlarged lacrimal and salivary glands in patients with EGPA may represent a primary EGPA involvement.

These findings suggest that rheumatologists need to be careful to make the final diagnosis of IgG4-related disease if the patients present with swollen lacrimal and salivary glands and show systemic inflammatory features such as elevated levels of serum $\mathrm{C}$ reactive protein, which are uncommon in IgG4-related disease. In addition, it is important to keep it in mind that serum IgG4 elevation and IgG4-positive plasma cell infiltration are not specific findings for IgG4-related disease. It has been widely reported that those findings can be detected in diverse chronic inflammatory diseases, questioning its specificity. ${ }^{16}$ Furthermore, the frequency of antineutrophil cytoplasmic antibody (ANCA) positivity in patients with EGPA is low, only up to $30 \%-40 \% ;^{17}$ therefore, histopathological findings of the swollen lacrimal and salivary glands are the key to discriminate EGPA from IgG4related disease in such cases. The accurate diagnosis is crucial to initiate the appropriate treatments and to elucidate the precise pathogenesis of both EGPA and IgG4-related disease.

Mitsuhiro Akiyama $\odot$, Yuko Kaneko, Tsutomu Takeuchi

A

\begin{tabular}{|c|c|c|c|c|c|c|c|c|c|c|c|}
\hline Authors & $\begin{array}{l}\text { Reported } \\
\text { year }\end{array}$ & $\begin{array}{l}\text { Age } \\
\text { (years) }\end{array}$ & Sex & $\begin{array}{l}\text { Mikulicz disease-like } \\
\text { symptoms }\end{array}$ & $\begin{array}{l}\text { Other } \\
\text { EGPA } \\
\text { symptoms }\end{array}$ & $\begin{array}{l}\text { Blood } \\
\text { eosinop } \\
\text { hil count } \\
\text { (cells } / \mu \mathrm{L} \text { ) }\end{array}$ & $\begin{array}{l}\% \text { of blood } \\
\text { eosinophil }\end{array}$ & $\begin{array}{l}\text { Serum } \\
\text { lgG4 } \\
\text { (mg/dL) }\end{array}$ & $\begin{array}{l}\text { Serum } \\
\text { IgE } \\
\text { (IU/mL) }\end{array}$ & $\begin{array}{l}\text { Serum C- } \\
\text { reactive } \\
\text { protein } \\
(\mathbf{m g} / \mathrm{dL})\end{array}$ & $\begin{array}{l}\text { ANCA } \\
\text { serology }\end{array}$ \\
\hline $\begin{array}{l}\text { Hanioka } \\
\text { Y et al. }\end{array}$ & 2012 & 72 & Male & $\begin{array}{l}\text { Enlarged bilateral lacrimal and } \\
\text { submandibular glands }\end{array}$ & $\begin{array}{l}\text { Asthma, } \\
\text { sinusitis, } \\
\text { skin, nerve }\end{array}$ & 2158 & 32.3 & 343 & 454 & 2.32 & $\begin{array}{l}\text { MPO- } \\
\text { ANCA }\end{array}$ \\
\hline $\begin{array}{l}\text { Ayuzawa } \\
\mathrm{N} \text { et al. }\end{array}$ & 2012 & 68 & Female & $\begin{array}{l}\text { Enlarged bilateral salivary } \\
\text { glands }\end{array}$ & $\begin{array}{l}\text { Asthma, } \\
\text { lungs, } \\
\text { kidney, skin, } \\
\text { nerve, joint }\end{array}$ & 13500 & 67.5 & 275 & 5398 & 8.10 & Negative \\
\hline $\begin{array}{l}\text { Akiyama } \\
\text { Ket al. }\end{array}$ & 2017 & 68 & Male & $\begin{array}{l}\text { Enlarged bilateral } \\
\text { submandibular glands, } \\
\text { enlarged right lacrimal gland, } \\
\text { thickening of left extraocular } \\
\text { muscles and infraorbital nerve }\end{array}$ & $\begin{array}{l}\text { Fever, } \\
\text { asthma, } \\
\text { sinusitis, } \\
\text { lungs, } \\
\text { nerve, joint }\end{array}$ & 4068 & 39.0 & 1500 & 26.5 & 2.36 & Negative \\
\hline $\begin{array}{l}\text { Takahas } \\
\text { hi K et al. }\end{array}$ & 2020 & 51 & Female & $\begin{array}{l}\text { Enlarged bilateral } \\
\text { submandibular glands }\end{array}$ & $\begin{array}{l}\text { Fever, } \\
\text { asthma, } \\
\text { lungs, skin, } \\
\text { joint }\end{array}$ & 3027 & 32.9 & 261 & 3052 & 2.76 & Negative \\
\hline
\end{tabular}

B

\begin{tabular}{|l|l|l|l|}
\hline Authors & $\begin{array}{l}\text { Reported } \\
\text { year }\end{array}$ & Biopsy site & Histopathological findings \\
\hline Khandwala MA et al. & 2010 & Enlarged lacrimal gland & Eosinophilic granulomas with giant cells. \\
\hline Ameli F et al. & 2011 & Enlarged lacrimal gland & $\begin{array}{l}\text { Eosinophilic granulomas surrounded by eosinophils, lymphocytes, histiocytes, and giant cells. Angiitis } \\
\text { with destruction of the vascular architecture along with intense inflammatory cell infiltrates. }\end{array}$ \\
\hline Tovoli F et al. & 2013 & Enlarged submandibular gland & $\begin{array}{l}\text { Eosinophilic granulomas with dendritic cells and histiocytic macrophages. The perivascular and } \\
\text { periductal eosinophilic and lymphocytic infiltrates. }\end{array}$ \\
\hline
\end{tabular}

Figure 1 Characteristics of EGPA complicated with Mikulicz disease-like manifestations. (A) Cases of EGPA complicated with lacrimal and salivary glands swelling along with elevated serum IgG4 levels. (B) Histopathological findings of the enlarged lacrimal and salivary glands of EGPA. EGPA, eosinophilic granulomatosis with polyangiitis. 
Division of Rheumatology, Department of Internal Medicine, Keio University School of Medicine, Shinjuku-ku, Tokyo, Japan

Correspondence to Dr Yuko Kaneko; ykaneko.z6@keio.jp

Contributors MA, YK and TT wrote and discussed the manuscript. All authors approved the final version of the manuscript.

Funding The authors have not declared a specific grant for this research from any funding agency in the public, commercial or not-for-profit sectors.

Competing interests YK has received grants or speaker fees from AbbVie, Astellas, Ayumi, Bristol-Myers Squibb, Chugai, Eisai, Eli Lilly, Hisamitsu, Jansen, Kissei, Pfizer, Sanofi, Takeda, Tanabe-Mitsubishi and UCB. TT has received research grants or speaking fees from Astellas Pharma Inc, Bristol-Myers K.K., Chugai Pharmaceutical Co, Ltd, Daiichi Sankyo Co., Ltd, Takeda Pharmaceutical Co., Ltd, Teijin Pharma Ltd, AbbVie GK, Asahi Kasei Pharma Corp., Mitsubishi Tanabe Pharma, Astra Zeneca K.K., Eli Lilly Japan K.K., Novartis Pharma K.K., AbbVie GK, Nippon Kayaku Co. Ltd, Janssen Pharmaceutical K.K., Taiho Pharmaceutical Co Ltd and Pfizer Japan Inc.

Patient and public involvement Patients and/or the public were not involved in the design, or conduct, or reporting, or dissemination plans of this research.

Patient consent for publication Not required.

Provenance and peer review Not commissioned; internally peer reviewed.

(c) Author(s) (or their employer(s)) 2020. No commercial re-use. See rights and permissions. Published by BMJ.

\section{A) Check for updates}

To cite Akiyama M, Kaneko Y, Takeuchi T. Ann Rheum Dis Epub ahead of print: [please include Day Month Year]. doi:10.1136/annrheumdis-2020-218124

Received 26 May 2020

Accepted 29 May 2020

\section{CDLinked}

https://doi.org/10.1136/annrheumdis-2020-218174

Ann Rheum Dis 2020;0:1-2. doi:10.1136/annrheumdis-2020-218124

ORCID iD

Mitsuhiro Akiyama http://orcid.org/0000-0001-5075-8977

\section{REFERENCES}

1 Vaglio A, Strehl JD, Manger B, et al. IgG4 immune response in Churg-Strauss syndrome. Ann Rheum Dis 2012:71:390-3.

2 Danlos F-X, Rossi GM, Blockmans D, et al. Antineutrophil cytoplasmic antibodyassociated vasculitides and IgG4-related disease: a new overlap syndrome. Autoimmun Rev 2017;16:1036-43.

3 Yoo J, Song JJ, Park Y-B, et al. Definite IgG4-related disease had no overlap with eosinophilic granulomatosis with polyangiitis in Korean patients: a pilot study in one centre. Clin Rheumatol 2020. doi:10.1007/s10067-020-05104-5

4 Yamamoto M, Takahashi H, Suzuki C, et al. Analysis of serum IgG subclasses in Churg-Strauss syndrome--the meaning of elevated serum levels of IgG4. Intern Med 2010:49:1365-70.

5 Akiyama M, Yasuoka H, Yoshimoto K, et al. Interleukin-4 contributes to the shift of balance of $\lg G$ subclasses toward $\lg G 4$ in IgG4-related disease. Cytokine 2018;110:416-9.

6 Akiyama M, Kaneko Y, Takeuchi T. Interleukin-4 as an emerging therapeutic target for lgG4-related disease. Ann Rheum Dis 2020:annrheumdis-2020-216961.

7 Akiyama M, Yasuoka H, Yamaoka K, et al. Enhanced lgG4 production by follicular helper $2 \mathrm{~T}$ cells and the involvement of follicular helper $1 \mathrm{~T}$ cells in the pathogenesis of IgG4-related disease. Arthritis Res Ther 2016;18:167.

8 Hanioka Y, Yamagami K, Yoshioka K, et al. Churg-Strauss syndrome concomitant with chronic symmetrical Dacryoadenitis suggesting Mikulicz's disease. Intern Med 2012:51:2457-61.

9 Ayuzawa N, Ubara Y, Keiichi S, et al. Churg-Strauss syndrome with a clinical condition similar to IgG4-related kidney disease: a case report. Intern Med 2012;51:1233-8.

10 Akiyama K, Yonezaki M, Dobashi H, et al. Case of EGPA and eosinophilic chronic rhinosinusitis concomitant with IgG4 related disease. Nihon Jibiinkoka Gakkai Kaiho 2017:120:123-30.

11 Takahashi K, Sadamatsu H, Tashiro H, et al. Eosinophilic granulomatous polyangiitis with IgG4 hypergammaglobulinaemia and salivary gland swelling. Respirol Case Rep 2020;8:e00552.

12 Akiyama M, Takeuchi T. Igg4-Related disease: beyond glucocorticoids. Drugs Aging 2018;35:275-87.

13 Khandwala MA, Vayalambrone D, Ong J, et al. Dacryoadenitis as a presenting feature of the Churg Strauss syndrome. Eye 2010;24:385-6.

14 Ameli F, Phang KS, Masir N. Churg-Strauss syndrome presenting with conjunctival and eyelid masses: a case report. Med J Malaysia 2011;66:517-9.

15 Tovoli F, Vannini A, Masi C, et al. Eosinophilic granulomatosis with polyangiitis of the major salivary glands: a case of sialadenitis in a young patient. Intern Med 2013;52:2131-4.

16 Anan R, Akiyama M, Kaneko Y, et al. Polymyositis with elevated serum lgG4 levels and abundant lgG4+ plasma cell infiltration: a case report and literature review. Medicine 2017:96:e8710.

17 Trivioli G, Terrier B, Vaglio A. Eosinophilic granulomatosis with polyangiitis: understanding the disease and its management. Rheumatology 2020;59:iii84-94. 